\title{
Variability of Mitochondrial Respiration in Relation to Sepsis-Induced Multiple Organ Dysfunction
}

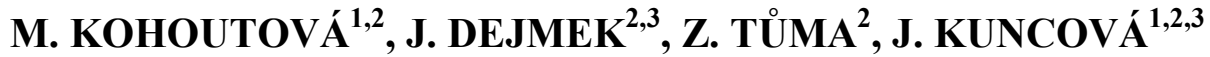 \\ ${ }^{1}$ Institute of Physiology, Faculty of Medicine in Plzeň, Charles University, Plzeň, Czech Republic, \\ ${ }^{2}$ Biomedical Centre, Faculty of Medicine in Plzeň, Charles University, Plzeň, Czech Republic, \\ ${ }^{3}$ Institute of Biophysics, Faculty of Medicine in Plzeň, Charles University, Plzeň, Czech Republic
}

Received May 18, 2018

Accepted September 12, 2018

\begin{abstract}
Summary
Ample experimental evidence suggests that sepsis could interfere with any mitochondrial function; however, the true role of mitochondrial dysfunction in the pathogenesis of sepsis-induced multiple organ dysfunction is still a matter of controversy. This review is primarily focused on mitochondrial oxygen consumption in various animal models of sepsis in relation to human disease and potential sources of variability in experimental results documenting decrease, increase or no change in mitochondrial respiration in various organs and species. To date, at least three possible explanations of sepsis-associated dysfunction of the mitochondrial respiratory system and consequently impaired energy production have been suggested: 1. Mitochondrial dysfunction is secondary to tissue hypoxia. 2. Mitochondria are challenged by various toxins or mediators of inflammation that impair oxygen utilization (cytopathic hypoxia). 3. Compromised mitochondrial respiration could be an active measure of survival strategy resembling stunning or hibernation. To reveal the true role of mitochondria in sepsis, sources of variability of experimental results based on animal species, models of sepsis, organs studied, or analytical approaches should be identified and minimized by the use of appropriate experimental models resembling human sepsis, wider use of larger animal species in preclinical studies, more detailed mapping of interspecies differences and organ-specific features of oxygen utilization in addition to use of complex and standardized protocols evaluating mitochondrial respiration.
\end{abstract}

\section{Key words}

Sepsis • Mitochondria • Oxygen consumption • Multiple organ dysfunction $\bullet$ Animal models

\section{Corresponding author}

J. Kuncová, Institute of Physiology, Faculty of Medicine in Plzeň, Charles University, Alej Svobody 76, 323 00, Plzeň, Czech Republic. E-mail: jitka.kuncova@lfp.cuni.cz

\section{Introduction}

Sepsis, life-threatening organ dysfunction caused by a dysregulated host response to infection, represents one of the most serious public health issues of the modern time. In the United States it affects more than 750,000 patients per year (Angus et al. 2001); its incidence is similar in Europe and probably even higher in low-income countries (Fleischmann et al. 2016). Mortality rate ranges between $30-70 \%$ in relation to severity of the disease, particularly to the number of dysfunctional organs (da Silva et al. 2008).

\section{Definition of sepsis}

In the course of past few decades, definition of sepsis has substantially changed. Originally, it was based mainly on the evidence of bacteremia or toxemia. In 1991, sepsis-1 definition was established as an infection or suspected infection leading to the onset of systemic inflammatory response syndrome (SIRS). SIRS diagnostic criteria (Table 1) were based on the precisely defined changes in body temperature, heart rate, respiratory functions, and white blood cell count (Bone et al. 1992). In addition, severity of the disease was classified in three categories - sepsis (present/suspect 
infection + at least 2 SIRS criteria), severe sepsis (disease complicated by organ dysfunction) and septic shock ("sepsis-induced hypotension persisting despite adequate fluid resuscitation"). Criteria of SIRS were further expanded in sepsis-2 definition in 2001 (Levy et al. 2003). More substantial modification of definition of sepsis was approved in 2016 at a consensus conference of the Society of Critical Care Medicine and the European Society of Intensive Care Medicine (Marik and Taeb
2017). This sepsis-3 definition is based on better understanding of the pathophysiology of the disease and emphasizes maladaptive host response to infection that results in organ dysfunction (Singer et al. 2016). Presence of SIRS is not further regarded as a crucial marker of sepsis as it could be associated with a desired response of the body to the infection challenge. Consequently, category of severe sepsis became needless.

Table 1. Definitions of sepsis.

\begin{tabular}{|c|c|c|}
\hline $\begin{array}{l}\text { SEPSIS-1 } \\
(1992) \\
\text { Suspected/documented infection + } \\
\text { SIRS criteria }\end{array}$ & $\begin{array}{l}\text { SEPSIS-2 } \\
(2003) \\
\text { Suspected/documented infection }+ \\
\text { extended SIRS criteria }\end{array}$ & $\begin{array}{l}\text { SEPSIS-3 } \\
(2016) \\
\text { Suspected/documented infection + } \\
\text { SOFA score }\end{array}$ \\
\hline $\begin{array}{l}\text { SIRS criteria } \\
\text { - } \text { Temperature } \\
\text { - Heart rate } \\
\text { - } \text { WBCC/Bands } \\
\text { - Respiratory rate/ } \mathrm{PaCO}_{2} \\
\text { Organ dysfunction } \\
\text { SBP, MAP, coagulation, bilirubin } \\
\text { concentration, urine output, creatinine } \\
\text { concentration, oxygen saturation }\end{array}$ & $\begin{array}{l}\text { Extended SIRS criteria } \\
\text { • General parameters } \\
\text { Temperature, heart rate, respiratory } \\
\text { rate, hyperglycemia without DM, } \\
\text { altered mental status, edema } \\
\text { • Inflammatory parameters } \\
\text { WBCC/Bands, CRP, procalcitonin } \\
\text { • Hemodynamic parameters } \\
\text { MAP, SBP, mixed venous oxygen } \\
\text { saturation, cardiac index } \\
\text { • Organ dysfunction } \\
\text { PaO }{ }_{2} \text {, urine output, creatinine } \\
\text { concentration, coagulation, platelet } \\
\text { count, liver function (bilirubin } \\
\text { concentration), gastrointestinal } \\
\text { motility } \\
\text { • Tissue perfusion } \\
\text { Lactate concentration, capillary refill }\end{array}$ & $\begin{array}{ll}\text { SOFA } & \\
\text { - } & \mathrm{PaO}_{2} / \mathrm{FiO}_{2} \text { ratio } \\
\text { - } & \text { Glasgow coma scale score } \\
\text { - } & \mathrm{MAP} \\
\text { - } & \text { Vasopressors } \\
\text { - } & \text { Serum creatinine } \\
\text { - } & \text { Bilirubin } \\
\text { - } & \text { Platelet count }\end{array}$ \\
\hline $\begin{array}{l}\text { Staging } \\
\text { Sepsis = infection }+\geq 2 \text { SIRS } \\
\text { Severe sepsis = sepsis }+ \text { organ } \\
\text { dysfunction, hypoperfusion, or } \\
\text { hypotension } \\
\text { Septic shock = sepsis }+ \text { hypotension } \\
\text { despite adequate fluid resuscitation }+ \\
\text { hypoperfusion or organ dysfunction }\end{array}$ & $\begin{array}{l}\text { Staging } \\
\text { Sepsis }=\text { infection }+\geq 1 \text { extended } \\
\text { SIRS } \\
\text { Severe sepsis }=\text { sepsis }+ \text { organ } \\
\text { dysfunction } \\
\text { Septic shock }=\text { sepsis }+ \text { refractory } \\
\text { hypotension unexplained by other } \\
\text { causes }\end{array}$ & $\begin{array}{l}\text { Staging } \\
\text { Sepsis = life-threatening organ } \\
\text { dysfunction caused by a dysregulated } \\
\text { host response to infection } \\
\text { Septic shock = a subset of sepsis in } \\
\text { which profound circulatory, cellular } \\
\text { and metabolic abnormalities are } \\
\text { associated with a greater risk of } \\
\text { mortality than with sepsis alone }\end{array}$ \\
\hline
\end{tabular}

Variables evaluated in diagnosis of sepsis. SIRS - systemic inflammatory response syndrome, WBCC - white blood cell count, $\mathrm{PaCO}_{2}-$ arterial partial pressure of $\mathrm{CO}_{2}$, SBP - systolic blood pressure, MAP - mean arterial pressure, DM - diabetes mellitus, CRP - C-reactive protein, $\mathrm{PaO}_{2}$ - arterial partial pressure of $\mathrm{O}_{2}$, SOFA - sepsis-related (sequential) organ failure assessment $\mathrm{score} \mathrm{FiO}_{2}-\mathrm{fraction}_{\mathrm{O}}$ inspired $\mathrm{O}_{2}$. 


\section{Pathophysiology of sepsis}

Sepsis is characterized by homeostatic dysbalance that could progress in multiple organ dysfunction (MOD), septic shock and death. Pathogen-associated molecular patterns (PAMPs) stimulate plasma complement and coagulation systems and bind to pattern recognition receptors on the cell membranes and/or intracellular organelles. The simultaneous attack on the multilevel body's defense mechanisms provokes both passive and active release of danger-associated molecular patterns (DAMPs) from dying cells or cells challenged by PAMPs, like heat shock proteins, genomic and mitochondrial DNA, or ATP (Sharma and Naidu 2016) and others. These molecules further invade the host's tissues causing increased expression and release of a number of inflammatory mediators and biomarkers including those that promote inflammatory response, those that fight against infection, membrane receptors and their downstream effectors, molecules released from damaged cells, chemicals associated with activation of the coagulation and complement systems, vasoactive substances, acute phase proteins, biomarkers of various organs dysfunction, and others (Angus and van der Poll 2013). To date, about 180 biomarkers of sepsis have been identified (Pierrakos and Vincent 2010). Dysregulated immune reaction along with hormonal dysbalance, disturbed activity of the autonomic nervous system and dysfunction of epithelial and endothelial cells lead to the loss of barriers tightness, changes in intermediary metabolism, and subsequently to organ dysfunction. MOD is frequently manifested by respiratory distress, myocardial depression, systemic vasodilatation, acute kidney injury, impaired liver function, disturbed gastrointestinal motility, and coagulopathy (Reinhart et al. 2012, Fig. 1).
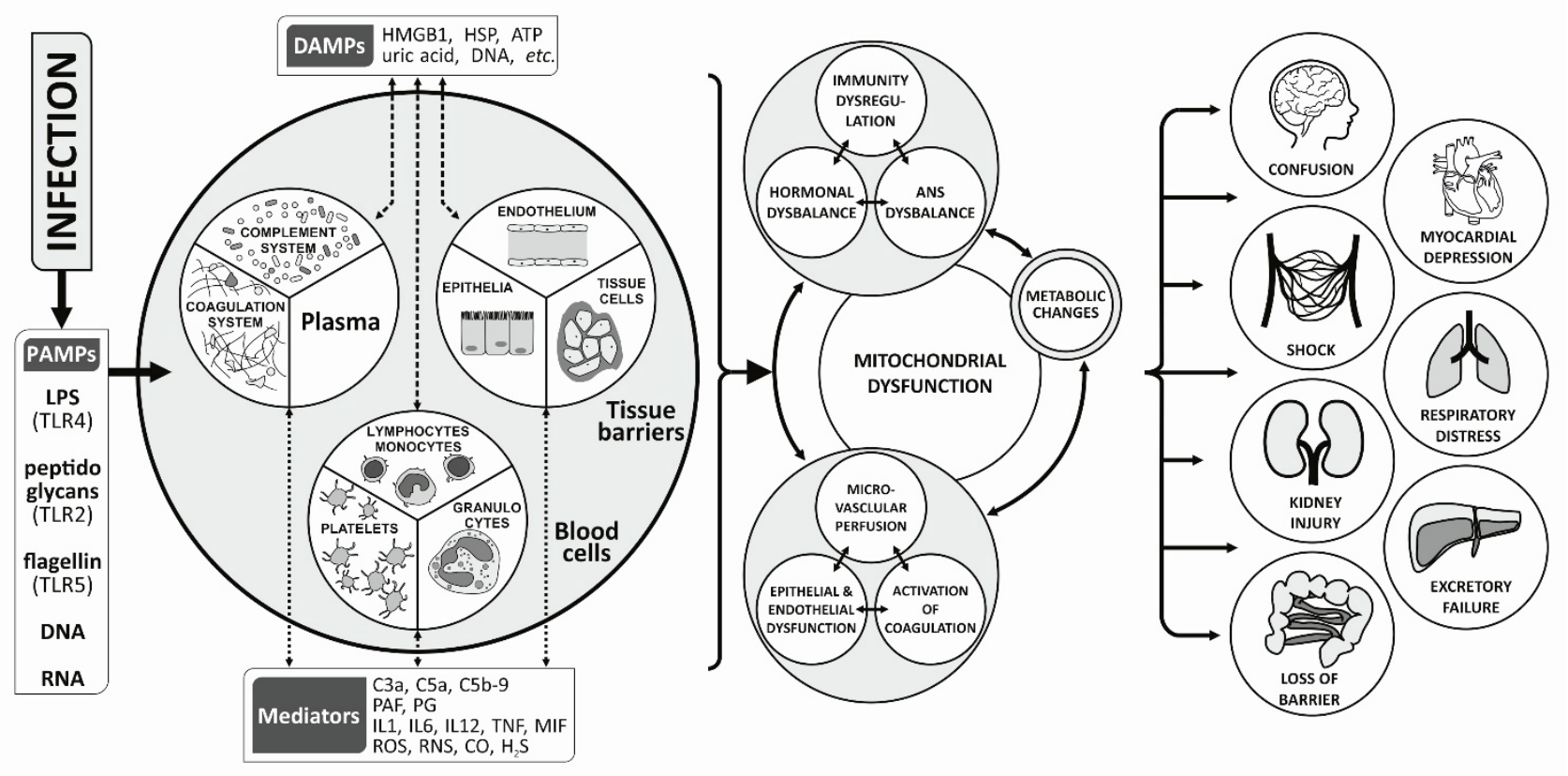

Fig. 1. Pathophysiology of sepsis. Pathogen-associated molecular patterns (PAMPs) bind to pattern recognition receptors in the cell membranes and intracellular organelles. Subsequent release of danger-associated molecular patterns (DAMPs) invading the host's tissues causes increased expression and release of inflammatory mediators and biomarkers. Dysregulated host response to the septic insult includes disturbed immune, endocrine, and autonomic nervous systems regulation, loss of barriers tightness, changes in intermediary metabolism, and subsequently multiple organ dysfunction. PAMPs - pathogen-associated molecular patterns, LPS lipopolysaccharide, TLR - Toll-like receptor, DNA - deoxyribonucleic acid, RNA - ribonucleic acid, DAMPs - danger-associated molecular patterns, HMGB1 - high mobility group box 1, HSP - heat shock protein, ATP - adenosine triphosphate, PAF - platelet-activating factor, PG - prostaglandins, IL - interleukin, TNF - tumor necrosis factor, MIF - macrophage migration inhibitory factor, ROS - reactive oxygen species, RNS - reactive nitrogen species, $\mathrm{CO}$ - carbon monoxide, $\mathrm{H}_{2} \mathrm{~S}$ - hydrogen sulfide, ANS - autonomic nervous system.

\section{Mitochondria in health}

Mitochondria are semi-autonomous cell organelles that are primarily designed to produce biologically available energy in the form of adenosine triphosphate (ATP). The inner mitochondrial membrane houses a sophisticated electrontransport system (ETS) designed to transfer electrons from appropriate substrates sequentially across multiheteromeric respiratory complexes (I to IV) and two mobile elements (coenzyme Q and cytochrome c) to their final acceptor, 
molecular oxygen (Fig. 2A). Gradually released energy is used to pump protons from the mitochondrial matrix into the intermembrane space thus generating a proton gradient driving ATP synthesis by complex V, ATP-synthase (Fig. 2). The substrates fueling directly or indirectly oxidative phosphorylation are mainly produced in the mitochondrial matrix in crucial metabolic processes, i.e. tricarboxylic acid (TCA) cycle and $\beta$-oxidation of fatty acids (Gnaiger 2014). Electrons for ETS are also provided by pyruvate dehydrogenase complex, glutamate dehydrogenase, sulfite oxidase (Velayutham et al. 2016), sulfide ubiquinone oxidoreductase, dihydroorotate dehydrogenase (Lemieux et al. 2017) or mitochondrial glycerol phosphate dehydrogenase (Mráček et al. 2013, Fig. 2B).

Besides their key role in energy production, mitochondria are also site of production of steroid hormones, heme, iron-sulfur clusters, and endogenous gases including reactive oxygen and nitrogen species that are required for cellular signaling. Mitochondria are also considered important regulators of intracellular calcium concentration; they generate heat thus contributing to temperature regulation and basal metabolic rate, initiate apoptotic cell death and may also have critical and multiple functions in the initiation of cell differentiation, cell-type determination, cell movement, and pattern formation (Maeda and Chida 2013).
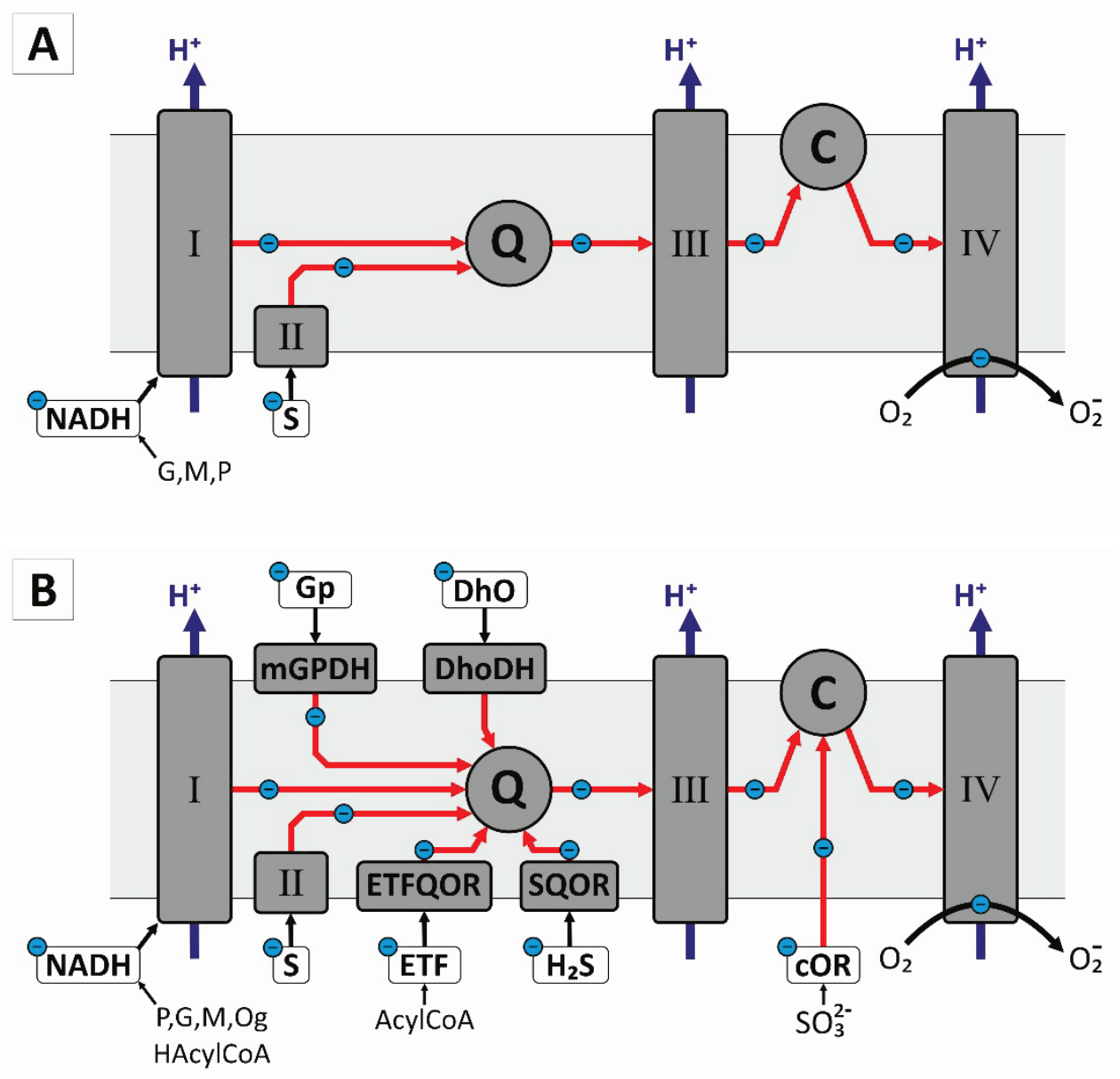

Fig. 2. Mitochondrial electron transport. Electron-transport system (ETS) serves to transfer electrons from substrates sequentially across four respiratory complexes (I to IV), two mobile carriers (coenzyme Q and cytochrome c) to final electron acceptor, molecular oxygen. (A) Simplified version of ETS reflecting widely used experimental protocols evaluating mitochondrial oxygen consumption. (B) More complex view on ETS including additional electron donors. Electron transport is coupled with proton pumping from the mitochondrial matrix into the intermembrane space thus generating a proton gradient driving ATP synthesis by complex $V$, ATP-synthase. Electrons fueling ETS come from substrates produced in tricarboxylic acid cycle and $\beta$-oxidation of fatty acids, from pyruvate dehydrogenase complex, glutamate dehydrogenase, mitochondrial glycerol phosphate dehydrogenase, sulfite oxidase, dihydro-orotate dehydrogenase, sulfide-ubiquinone oxidoreductase, and choline dehydrogenase (not shown). II, III, IV - complexes of electron-transport system, $\mathrm{O}$ - electron, $\mathrm{H}^{+}$- proton, $\mathrm{Q}$ - coenzyme $\mathrm{Q}, \mathrm{c}$ - cytochrome $\mathrm{c}, \mathrm{O}_{2}$ - oxygen, $\mathrm{NADH}$ - nicotinamide adenine dinucleotide, G - glutamate, M - malate, $\mathrm{P}$ - pyruvate, $\mathrm{Og}$ - oxoglutarate, HAcylCoa - hydroxyacyl-coenzyme A, S - succinate, $\mathrm{Gp}$ - glycerol phosphate, DhO - hydroxyorotate, $\mathrm{H}_{2} \mathrm{~S}$ - hydrogen sulfide, $\mathrm{mGPDH}$ - mitochondrial glycerol phosphate dehydrogenase, AcylCoA - acyl coenzyme A, ETF - electron transferring flavoprotein, SQOR - sulfide:quinone oxidoreductase, ETFQOR - electrontransfer flavoprotein:ubiquinone oxidoreductase, $\mathrm{COR}-$ cytochrome $\mathrm{c}$ oxidoreductase, $\mathrm{SO}_{3}{ }^{2-}-$ sulfite anion. 


\section{Mitochondria in sepsis}

Multiple experimental data on animals as well as humans suggest that exaggerated inflammatory response could interfere with any mitochondrial function; i.e. appropriate production of reactive oxygen and nitrogen species (recently reviewed by Duvigneau and Kozlov 2017), intracellular calcium homeostasis (Pinto et al. 2017), mitochondrial biogenesis and turnover (Inata et al. 2018), or regulation of apoptosis (Chen et al. 2017). This review is primarily focused on mitochondrial oxygen consumption in various animal models of sepsis in relation to human disease. Despite intense research in this field, the precise role of mitochondria in the chain of events leading to MOD is still a matter of controversy. So far reported experimental data on changes in mitochondrial respiration are far from being uniform and seem to depend on a number of factors including the organ studied, selected model of sepsis, animal species, severity and phase of the disease, and the experimental set-up (Singer 2014). Interestingly, despite frequently suggested key role of mitochondrial bioenergetics in the development and progression of MOD, the most frequent finding in experimental studies dealing with mitochondrial respiration or respiratory enzymes activities in various rodent models of sepsis was unchanged oxygen consumption by the heart, liver and skeletal muscle mitochondria (Jeger et al. 2013). However, it should be noted that similar number of studies reported sepsis-associated decrease or even increase in mitochondrial oxygen consumption in above mentioned organs (Jeger et al. 2013) and that unchanged respiration does not necessarily mean that the energy production is appropriately adjusted to the tissue needs (Dyson and Singer 2011). In general, there are at least three possible explanations of sepsis-associated dysfunction of the mitochondrial respiratory system and consequently impaired energy production (Fig. 3):

1. Increased oxygen demand associated with immune system activation, elevated body temperature, and increased metabolic rate together with impaired diffusion processes in microcirculation lead to tissue hypoxia that is reflected by decreased oxygen consumption in the mitochondria and impaired ATP generation (Kozlov et al. 2017). In such view, mitochondria would be victims of pathological processes initiated elsewhere and would only follow inadequate oxygen delivery with insufficient energy production. As reviewed by Chioléro et al. (1997), sepsis is frequently associated with increased metabolic rate, protein and fat catabolism, negative nitrogen balance, hyperglycemia, and insulin resistance. However, these metabolic changes are not correlated with the body temperature and severity of the disease, nor they seem to be in causal relationship to hyperdynamic pattern of circulation, typical for SIRS in humans (Kreymann et al. 1993). Although alterations in microcirculatory blood flow have been frequently identified in sepsis (De Backer et al. 2002), true tissue hypoxia manifested by decreased tissue $\mathrm{pO}_{2}$ was regularly reported mainly in hypodynamic stages of sepsis or short-term rodent models of endotoxemia (Dyson et al. 2011), where decline in tissue perfusion resulting in decreased tissue oxygen tension could be regarded as a predictable consequence (Matejovic et al. 2011). In addition, tissue $\mathrm{pO}_{2}$ does not reflect only oxygen delivery to tissues, but rather a balance between oxygen supply and its cellular consumption. Hypoxic theory of mitochondrial dysfunction in sepsis was challenged by studies demonstrating no effect of improved tissue perfusion on the recovery from sepsis (Gattinoni et al. 1995, Hayes et al. 1997). Taken together, despite an ample evidence of individual factors contributing to the aforementioned chain of events leading to an energy crisis during sepsis, their poor correlation argues against the simple passive role of mitochondria in the progression of the disease.

2. Mitochondria could be directly challenged by DAMPs and mediators of inflammation that cause decrease in oxygen consumption in conditions of preserved tissue blood flow and oxygen tension. The putative inability of mitochondria to consume oxygen as a mechanism contributing to organ dysfunction in sepsis was suggested by Fink and termed cytopathic hypoxia (Fink 1997).

As mentioned above, unchanged or even increased tissue oxygen tension was repeatedly reported in the skeletal muscles of septic patients (Boekstegers et al. 1991, Boekstegers et al. 1994) as well as decreased oxygen consumption and ATP generation by skeletal muscle mitochondria (Brealy et al. 2002, Fredriksson et al. 2006), findings that would fit the theory of cytopathic hypoxia. However, data obtained from critical tissues in animal resuscitated models are less convincing. For example, conflicting results were obtained from the liver, intestinal mucosa or kidneys where both decreased and unchanged tissue $\mathrm{pO}_{2}$ were documented (Lund et al. 1995, Dyson et al. 2011). In addition, results of studies on mitochondrial respiration in these organs display 
strong variation thus not providing compelling evidence of impaired oxygen utilization preceding overt organ dysfunction (Patil et al. 2014, Porta et al. 2006). Nevertheless, numerous data suggest that mitochondrial oxygen processing could be significantly affected in response to various mediators of inflammation. Among them, reactive oxygen and nitrogen species, carbon monoxide and hydrogen sulfide have drawn more attention due to their site of origin and quite consistently reported dual effect on mitochondrial electron transport (Duvigneau and Kozlov 2017, Kozlov et al. 2017, Módis et al. 2014).

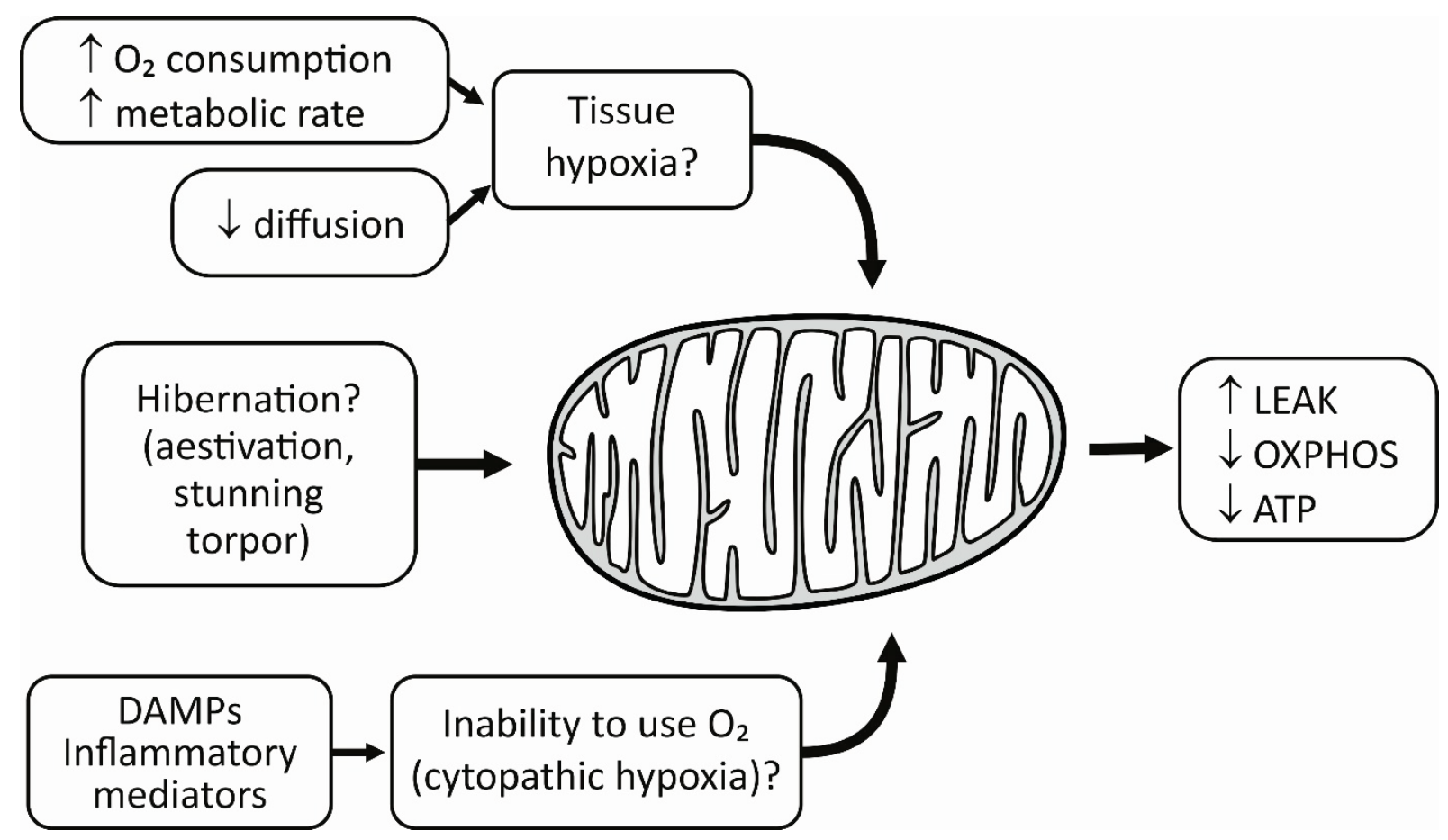

Fig. 3. The role of mitochondria in sepsis - 3 possible explanations of sepsis-associated dysfunction of the mitochondrial respiratory system and energy production. 1. Increased oxygen demand together with impaired diffusion processes in microcirculation leads to tissue hypoxia manifested by decreased oxygen consumption and impaired ATP generation. 2. Mitochondria could be directly challenged by DAMPs and mediators of inflammation that cause decrease in oxygen consumption in conditions of preserved tissue blood flow and oxygen tension. 3. Reduced oxygen consumption could be related to the active role of mitochondria in orchestration of survival strategy resembling stunning or hibernation. These processes could lead to an increase in the mitochondrial respiratory state LEAK, decrease in oxidative phosphorylation (OXPHOS) and limited ATP production. DAMPs - danger-associated molecular patterns, $\mathrm{O}_{2}-$ oxygen, ATP - adenosine triphosphate).

3. Reduced oxygen consumption could be related to the active role of mitochondria in orchestration of survival strategy resembling stunning or hibernation, characterized by regional contractile dysfunction of myocardium due to compromised oxygen supply (Singer 2017). Both phenomena were originally described in the hearts subjected to ischemia. The term stunned myocardium was initially used to characterize an abnormal contractile function of the left ventricle persisting for hours or days after coronary occlusion lasting not more than $15 \mathrm{~min}$ and not being accompanied with cell death (Braunwald and Kloner 1982, Heyndrickx et al. 1975). Hibernation was related to chronically compromised coronary perfusion associated with impaired left ventricular function that could be completely restored if blood flow was returned to normal
(Braunwald and Rutherford 1986, Rahimtoola 1993). Ischemia-induced hibernation is regarded as a regulatory measure that maintains myocardial integrity and viability (Heusch et al. 2005). At the cellular level, both mechanisms overlap being accompanied with metabolic adaptation characterized by shifting energy production away from oxidative phosphorylation and oxygen utilization. Many features of this metabolic adjustment have been identified also in human and mouse cardiomyocytes challenged by sepsis or endotoxemia including downregulation of enzymes in TCA cycle, suppression of catabolism of energy substrates including fatty acids, glucose and ketone bodies, accumulation of glycogen and triacylglycerols in the heart (Matkowich et al. 2017, Umbarawan et al. 2017), elevated pyruvate dehydrogenase kinase activity leading to suppression of 
pyruvate dehydrogenase (Standage et al. 2017) or decreased mitochondrial biogenesis (Lancel et al. 2009). In contrast, no changes in the levels of TCA intermediates and rather increased than decreased mitochondrial biogenesis were detected in the hearts of septic rats (Hotchkiss et al. 1991, Vanasco et al. 2014). More importantly, studies dealing with recovery from sepsis suggested that better energy-producing fatty acid catabolism was associated with survival of the fittest in sepsis (Langley et al. 2013) and that PPAR $\alpha$ expression (peroxisome proliferator-activated receptor alpha marker of mitochondrial biogenesis) and increased fatty acid oxidation were associated with the hyperdynamic cardiac response early in the course of sepsis and decreased morbidity and mortality (Standage et al. 2017). Some clinical studies on sepsis-induced myocardial depression indicated that left ventricular systolic (but not diastolic) dysfunction could be associated with improved outcome of sepsis (Jardin et al. 1999, Landesberg et al. 2012, Parker et al. 1984), however, recently published systematic review and meta-analysis of the data on newly diagnosed left ventricular systolic dysfunction in critically ill patients admitted to the intensive care unit with severe sepsis or septic shock concluded that the presence of new left ventricular systolic dysfunction is neither a sensitive nor a specific predictor of mortality (Sevilla Berrios et al. 2014).

In conclusion, although numerous data indicate substantial role of mitochondria in sepsis-induced MOD, none of the proposed hypotheses seems to be supported by convincing experimental and clinical evidence.

\section{Potential sources of variability}

In the literature, dysfunctional mitochondrial respiration is usually reported as universal feature of sepsis-induced organ failure and conclusions are made across the animal species, models of sepsis, analyzed organs or cells, and methods used for analysis of mitochondrial oxygen consumption. For example, the classical study by Brealey et al. (2002) performed on skeletal muscle biopsies taken from 28 septic patients and 9 controls recruited from orthopedic department showed an association between nitric oxide overproduction, antioxidant depletion, mitochondrial dysfunction, and decreased ATP concentrations that related to severity of the disease and eventual outcome. However, results and conclusions from this important work (646 citations in WoS) were taken as applicable on mitochondrial function of organs crucial in the development of MOD, like kidneys or heart (Dennis and Wittig, 2017, Gomez et al. 2014, Martin et al. 2017). Experimental studies dealing with mitochondrial respiration in these organs are relatively numerous for heart, but rare for kidneys (Jeger et al. 2013) and report conflicting results. The putative sources of considerable variability of sepsis-related mitochondrial oxygen consumption are discussed below.

1. In humans, sepsis per se is an extremely variable entity due to heterogeneous genetic background, frequent co-morbidities (diabetes mellitus, chronic kidney injury, heart failure, tumors etc.), physical fitness, age, source and degree of the triggering insult and its type (Christaki and Giamarellos-Bourboulis 2014, Giraldo et al. 2009, Villar et al. 2004). In addition, therapeutic interventions could have dual effect on metabolic turnover and mitochondrial respiration (Chioléro et al. 1997).

2. Species differences. Experimental animals used in the research on sepsis include a number of mammalian species from small rodents to pigs and primates (Fink 2014). At the end of April 2018, a simple query "given species and sepsis" in PubMed provided $13,000 / 9,000 / 2,800 / 2,400 / 2,000 / 700 / 300$ hits for mouse/ $\mathrm{rat} / \mathrm{dog} / \mathrm{pig} / \mathrm{rabbit} / \mathrm{cat} /$ baboon (reviews not excluded) with the highest counts for mouse (approx. 500-800 hits per year over the past 10 years). The use of laboratory rodents (namely mouse and rat) has been challenged by a number of studies pointing out substantial morphological and functional differences that could be related to discrepancies in the progression and outcome of sepsis between these species and humans. Besides well-known differences in the life-span, body weight, anatomy and functions of the organ systems (cardiovascular, urinary, gastrointestinal - Beuchat 1990, Kararli 1995, Milani-Nejad and Janssen 2014), speciesdependent variations in the genetic background (Seok et al. 2013), immune system (Mestas and Hughes 2004), intermediary and drug metabolism (Fujiwara et al. 2018, MacDonald et al. 2011, Mathew et al. 2017), production of reactive oxygen species (Barja 2007), susceptibility to infection (Cross et al. 1993), or ability to enter the metabolic torpor response (Schubert et al. 2010) might be directly related to poor outcome of clinical trials documenting no benefit or even deleterious impact of agents that exerted promising effects in animal experiments (Deitch 2005, Fink 2014).

3. Models of septic insult. Sepsis is an enormously complex condition that is difficult to be 
reproduced in experimental setting (Marshall et al. 2005). Selected aspects of processes associated with the impact of the disease on individual cell types can be studied in vitro on cultured tissue cells or freshly isolated blood cells challenged by septic plasma (Mariano et al. 2008, Sjövall et al. 2010). Blood cells isolated from septic patients (leukocytes and platelets) also represent the only easily available biological material that can be used to measure mitochondrial oxygen consumption in humans (Belikova et al. 2007, Puskarich et al. 2016). However, applicability of the results of these studies on mitochondrial functions of solid organs is limited as they are not in direct contact with blood. Leukocytes and platelets are also those cells that are considered major producers of many inflammatory mediators. More complex imitation of septic conditions can be achieved using in vivo animal models. Of note, it is extremely difficult to find more than two research groups using exactly the same animal model of sepsis. Besides aforementioned animal species used in sepsis research, the method of disease induction, performance and timing of resuscitation and sampling, age and sex of experimental animals, their genetic background and absence of complicating diseases represent factors contributing to the extreme variability of the research results in the field of sepsis-induced mitochondrial dysfunction (Singer 2007). Over the past two decades, various models of sepsis on experimental animals have been extensively reviewed (Deitch 1998, Freise et al. 2001, van der Poll 2012, Zanotti-Cavazzoni and Goldfarb 2009) with emphasis on their relevance to human disease (Dyson and Singer 2009, Esmon 2004, Poli-deFigueiredo et al. 2008, Rittirsch et al. 2007), translational potential (Dejager et al. 2011, Fink 2014, Pitts and Simpson 2010), particular process to be studied (Doi et al. 2009, Fink 2008, Siempos et al. 2014) or animal species used (Lewis et al. 2016, Redl and Bahrami 2005, Stortz et al. 2017). The list of some biological models used in sepsis research is shown in Table 2.

4. Mitochondrial diversity. Mitochondrial DNA diversity is a well-known phenomenon used to make various inferences about the origins of modern humans (Cann et al. 1987, Stoneking and Soodyall 1996), phylogeny (Hurst and Jiggins 2005) or in forensic analysis (Melton and Nelson 2001). Tissue diversity of mitochondrial morphology, quantity and composition has been reported in mouse tissues (Mootha et al. 2003, Pagliarini et al. 2008). An excellent study by Benard et al. (2006) determined the composition and functional features of the respiratory chain in muscle, heart, liver, kidney, and brain of male Wistar rats and concluded that tissues could be categorized at least into three groups: muscle and heart, brain, and liver and kidney. Tissuedependent values of mitochondrial oxygen consumption were also reported in porcine skeletal muscle, liver, and kidney (Porta et al. 2006) and rat heart, liver, brain and kidney (Pecinová et al. 2011). It is thus clear that conclusions about sepsis-driven changes in mitochondrial oxygen consumption made across different organs could be misleading.

5. Analytical methods. Although mitochondrial oxygen consumption would seem to be a robust and stable parameter if given experimental conditions are maintained, reproducibility and comparability of mitochondrial analyses depend on a number of factors that arise from the preparation of organelles and the methodological approach used. Oxygen consumption could be studied on isolated mitochondria, tissue homogenates, isolated cells or permeabilized tissue samples (Kuznetsov et al. 2008). Isolation of mitochondria by differential centrifugation could lead to loss of organelles that were damaged by pathological processes induced by sepsis and subsequent determination of oxygen consumption then could give misleading results (Piper et al. 1985). Measurement of mitochondrial respiration on the whole cells is suitable for blood cells, isolated hepatocytes or cultured tissue cells, quality of which can be dependent on isolation procedure (Frezza et al. 2007). In particular, platelets and white blood cells can be stimulated by mechanical manipulation and contact with media and laboratory plastics (Kramer et al. 2014). Mechanical and chemical permeabilization of the tissue is well standardized for skeletal and cardiac muscles, reported for the liver tissue, but not yet available for other organs. Tissue homogenates are widely used in the evaluation of mitochondrial respiration; however, the homogenization itself is difficult to be standardized and can damage intracellular organelles (Cantó and Garcia-Roves 2015).

Activity of individual respiratory complexes can be determined using methods based on analysis of oxygen consumption (using classical oxygraphy, high resolution respirometry, or fluorescent probes) in freshly dissected tissue or isolated mitochondria or by classical spectrophotometric methods determining their enzymatic activities (Perry et al. 2013). In vivo, mitochondrial respiration is substantially dependent not only on the ability of ETS to transport electrons and to couple it with 
phosphorylating process, but also on the availability of substrates and presence of regulatory factors (Ozkok et al. 2016, Schöpf et al. 2016, Tantama et al. 2013). Such a situation is difficult to be reproduced in ex vivo conditions. In classical oxygraphy or more sophisticated high resolution respirometry, saturating concentrations of substrates are provided (Pesta and Gnaiger 2012), whereas in the living cells in tissues challenged by SIRS, availability of natural substrates could be challenged (Bar-Or et al. 2018, Waltz et al. 2016). In addition, various oxygraphic protocols only partly reproduce the situation in vivo, where the substrates providing electrons to ETS are more numerous. In the most frequent protocol used to evaluate activity of complex 1, only glutamate and malate are used as substrates providing NADH, although the real situation is much more variable
(Fig. 2B). For example, combinations of substrates malate + glutamate could give different results than malate + pyruvate (Gnaiger 2009, Lemieux et al. 2017). The total oxygen consumption by mitochondria is not dependent only on convergent flow of electrons from complexes I and II on coenzyme Q, but could be also affected by functional integrity of electron transporting flavoprotein and other electron donors that are not regularly included in analyses of mitochondrial respiration, like mGPDH (Ramos-Filho et al. 2015, Rauchová et al. 2014). In addition, the parameter determined by oxygraphic techniques after addition of substrates and ADP might not be true oxygen consumption by in situ mitochondria, but capacity of ETS to consume oxygen under coupled conditions (i.e. OXPHOS capacity; Wüst et al. 2015).

Table 2. Experimental models of sepsis.

\section{In vitro Models}

Cultured cells

Blood cells

Freshly isolated tissue cells from septic animals
Do not reproduce true sepsis (-)

Suitable to study subcellular pathways in the particular cell types $(+)$

Blood cells challenged by sepsis can be obtained from human patients $(+)$

\section{In vivo Models}

\section{Peritonitis models}

\begin{tabular}{ll} 
& Polymicrobial $(+)$ \\
Cecal ligation and puncture & Presence of infection focus $(+)$ \\
Bacteria and fibrin clot implantation & Prolonged elevation of cytokines $(+)$ \\
Colon ascendens stent peritonitis & Variable duration and severity $(-)$ \\
Cecal slurry injection & Approach true human sepsis $(+)$ \\
Autologous feces inoculation & Poor control of bacterial load $(-)$ \\
& Surgical training required $(-)$ \\
\hline Intravascular models & Resuscitation desirable $(-)$ \\
\hline & \\
Bacterial injection & Standardized, simple and reproducible $(+)$ \\
Endotoxin injection or infusion & Dependent on the type of toxin, its dose, route of \\
administration, host species $(-)$ & Different from peritonitis models $(-)$ \\
& Do not mimic human sepsis $(-)$ \\
& Strictly dependent on given PRR $(-)$ \\
High levels of inflammatory cytokines peak earlier $(-)$ & Usually fulminant disease $(-)$ \\
& Suitable to study isolated effects of given endotoxin $(+)$
\end{tabular}

List of experimental models of sepsis with their advantages (+) and disadvantages (-). PRR - pattern recognition receptor. 


\section{Perspectives}

Despite substantial progress in understanding of pathophysiology of sepsis and identification of a number of molecules that could be potentially beneficial in the treatment of sepsis, clinical trials designed to approve the use of these agents in the human medicine have been remarkably unsuccessful (Fink 2014). To improve the translational potential of animal experiments, several strategies have been suggested.

Modern omics technologies enable identification of multiple pathways potentially involved in the onset and progression of MOD in human septic patients (Evangelatos et al. 2018, Langley et al. 2013, Liu et al. 2014). Strategy of "reverse translation" based on identification of these pathways in humans and their subsequent verification on appropriate animal model would help to avoid analysis and fruitless translation of phenomena that are strictly species-specific (Efron et al. 2015).

The animal models are being continuously improved to better reproduce key features of human sepsis (Stortz et al. 2017). In rodents, use of cecal ligation and puncture (CLP) resuscitated model is preferred to endotoxin and peritonitis models without resuscitation (Dejager et al. 2011). Experiments on small laboratory rodents will also enable evaluation of impact of age and various comorbidities on the pathophysiology and outcome of sepsis (Loftus et al. 2018, Miyaji et al. 2003). In contrast to vast majority of sepsis models in rodents, porcine experimental peritonitis is regularly associated with hyperdynamic pattern of circulation, increased oxygen delivery and unchanged systemic oxygen uptake, findings that mimic the course of human disease (Benes et al. 2011, Chvojka et al. 2008). Wider use of larger animal species could be recommended in preclinical studies designed to approve the use of new pharmacological agents for the treatment of sepsis.

To answer the question if mitochondrial dysfunction is a real determinant of induction/progression of sepsis-related organ dysfunction further intense research work is still needed. Research in basic mitochondrial physiology requires more detailed mapping of interspecies differences and organ-specific features of oxygen utilization in addition to use of complex and standardized protocols evaluating mitochondrial respiration (Lemieux et al. 2017). Porcine models of sepsis allow repeated sampling that would help to answer many questions concerning progression of mitochondrial dysfunction and its impact on MOD (Matejovic et al. 2016).

\section{Conflict of Interest}

There is no conflict of interest.

\section{Acknowledgements}

The study was supported by the Charles University Research Fund (Progres Q39), by the National Sustainability Program I (NPUI) Nr. LO1503 provided by the MEYS CR, project No. CZ.02.1.01/0.0/0.0/ 16_019/0000787 „Fighting INfectious Diseases“, awarded by the MEYS CR, financed from EFRR, the Specific Student Research Project No. 260394/2017 of the Charles University in Prague, and by the Grant Agency of the Czech Republic (project Nr. 15-15716S).

\section{References}

ANGUS DC, LINDE-ZWIRBLE WT, LIDICKER J, CLERMONT G, CARCILLO J, PINSKY MR: Epidemiology of severe sepsis in the United States: analysis of incidence, outcome, and associated costs of care. Crit Care Med 29: 1303-1310, 2001.

ANGUS DC, VAN DER POLL T: Severe sepsis and septic shock. $N$ Engl J Med 369: 840-851, 2013.

BAR-OR D, CARRICK M, TANNER A, LIESER MJ, RAEL LT, BRODY E: Overcoming the Warburg effect: Is it the key to survival in sepsis? J Crit Care 43: 197-201, 2018.

BARJA G: Mitochondrial oxygen consumption and reactive oxygen species production are independently modulated: implications for aging studies. Rejuvenation Res 10: 215-224, 2007.

BELIKOVA I, LUKASZEWICZ AC, FAIVRE V, DAMOISEL C, SINGER M, PAYEN D: Oxygen consumption of human peripheral blood mononuclear cells in severe human sepsis. Crit Care Med 35: 2702-2708, 2007.

BENARD G, FAUSTIN B, PASSERIEUX E, GALINIER A, ROCHER C, BELLANCE N, DELAGE JP, CASTEILLA L, LETELLIER T, ROSSIGNOL R: Physiological diversity of mitochondrial oxidative phosphorylation. Am J Physiol 291: C1172-C1182, 2006. 
BENES J, CHVOJKA J, SYKORA R, RADEJ J, KROUZECKY A, NOVAK I, MATEJOVIC M: Searching for mechanisms that matter in early septic acute kidney injury: an experimental study. Crit Care 15: R256, 2011.

BEUCHAT CA: Body size, medullary thickness, and urine concentrating ability in mammals. Am J Physiol 258: R298-R308, 1990.

BOEKSTEGERS P, WEIDENHÖFER S, KAPSNER T, WERDAN K: Skeletal muscle partial pressure of oxygen in patients with sepsis. Crit Care Med 22: 640-650, 1994.

BOEKSTEGERS P, WEIDENHÖFER S, PILZ G, WERDAN K: Peripheral oxygen availability within skeletal muscle in sepsis and septic shock: comparison to limited infection and cardiogenic shock. Infection 19: 317-323, 1991.

BONE RC, BALK RA, CERRA FB, DELLINGER RP, FEIN AM, KNAUS WA, SCHEIN RM, SIBBALD WJ: Definitions for sepsis and organ failure and guidelines for the use of innovative therapies in sepsis. The ACCP/SCCM Consensus Conference Committee. American College of Chest Physicians/Society of Critical Care Medicine. Chest 101: 1644-1655, 1992.

BRAUNWALD E, KLONER RA: The stunned myocardium: prolonged, postischemic ventricular dysfunction. Circulation 66: 1146-1149, 1982.

BRAUNWALD E, RUTHERFORD JD: Reversible ischemic left ventricular dysfunction: evidence for the "hibernating myocardium". J Am Coll Cardiol 8: 1467-1470, 1986.

BREALEY D, BRAND M, HARGREAVES I, HEALES S, LAND J, SMOLENSKI R, DAVIES NA, COOPER CE, SINGER M: Association between mitochondrial dysfunction and severity and outcome of septic shock. Lancet 360: 219-223, 2002.

CANN RL, STONEKING M, WILSON AC: Mitochondrial DNA and human evolution. Nature 325: 31-36, 1987.

CANTÓ C, GARCIA-ROVES PM: High-resolution respirometry for mitochondrial characterization of ex vivo mouse tissues. Curr Protoc Mouse Biol 5: 135-153, 2015.

CHEN G, LI X, HUANG M, ZHOU X, LI Y, MAO X, BAI J: The role of thioredoxin-1 in suppression sepsis through inhibiting mitochondrial-induced apoptosis in spleen. Shock 47: 753-758, 2017.

CHIOLÉRO R, REVELLY JP, TAPPY L: Energy metabolism in sepsis and injury. Nutrition 13: 45S-51S, 1997.

CHRISTAKI E, GIAMARELLOS-BOURBOULIS EJ: The beginning of personalized medicine in sepsis: small steps to a bright future. Clin Genet 86: 56-61, 2014.

CHVOJKA J, SYKORA R, KROUZECKY A, RADEJ J, VARNEROVA V, KARVUNIDIS T, HES O, NOVAK I, RADERMACHER P, MATEJOVIC M: Renal haemodynamic, microcirculatory, metabolic and histopathological responses to peritonitis-induced septic shock in pigs. Crit Care 12: R164, 2008.

CROSS AS, OPAL SM, SADOFF JC, GEMSKI P: Choice of bacteria in animal models of sepsis. Infect Immun 61: 2741-2747, 1993.

DA SILVA ED, KOCH NOGUEIRA PC, RUSSO ZAMATARO TM, DE CARVALHO WB, PETRILLI AS: Risk factors for death in children and adolescents with cancer and sepsis/septic shock. J Pediatr Hematol Oncol 30: 513-518, 2008.

DE BACKER D, CRETEUR J, PREISER JC, DUBOIS MJ, VINCENT JL: Microvascular blood flow is altered in patients with sepsis. Am J Respir Crit Care Med 166: 98-104, 2002.

DEITCH EA: Rodent models of intra-abdominal infection. Shock 24: 19-23, 2005.

DEITCH EA: Animal models of sepsis and shock: A review and lessons learned. Shock 9: 1-11, 1998.

DEJAGER L, PINHEIRO I, DEJONCKHEERE E, LIBERT C: Cecal ligation and puncture: the gold standard model for polymicrobial sepsis? Trends Microbiol 19: 198-208, 2011.

DENNIS JM, WITTING PK: Protective role for antioxidants in acute kidney disease. Nutrients 9: 718, 2017.

DOI K, LEELAHAVANICHKUL A, YUEN PST, STAR RA: Animal models of sepsis and sepsis-induced kidney injury. J Clin Invest 119: 2868-2878, 2009.

DUVIGNEAU JC, KOZLOV AV: Pathological impact of the interaction of no and co with mitochondria in critical care diseases. Front Med 4: 223, 2017.

DYSON A, RUDIGER A, SINGER M: Temporal changes in tissue cardiorespiratory function during faecal peritonitis. Intensive Care Med 37: 1192-1200, 2011.

DYSON A, SINGER M: Animal models of sepsis: why does preclinical efficacy fail to translate to the clinical setting? Crit Care Med 37 (1 Suppl): S30-S37, 2009. 
DYSON A, SINGER M: Tissue oxygen tension monitoring: will it fill the void? Curr Opin Crit Care 17: 281-289, 2011.

EFRON PA, MOHR AM, MOORE FA, MOLDAWER LL: The future of murine sepsis and trauma research models. J Leukoc Biol 98: 945-952, 2015.

ESMON CT: Why do animal models (sometimes) fail to mimic human sepsis? Crit Care Med 32 (5 Suppl): S219-S222, 2004.

EVANGELATOS N, SATYAMOORTHY K, LEVIDOU G, BAUER P, BRAND H, KOUSKOUTI C, LEHRACH H, BRAND A: Multi-omics research trends in sepsis: a bibliometric, comparative analysis between the United States, the European Union 28 Member States, and China. OMICS 22: 190-197, 2018.

FINK M: Cytopathic hypoxia in sepsis. Acta Anaesthesiol Scand Suppl 110: 87-95, 1997.

FINK MP: Animal models of sepsis. Virulence 5: 143-153, 2014.

FINK MP: Animal models of sepsis and its complications. Kidney Int 74: 991-993, 2008.

FLEISCHMANN C, SCHERAG A, ADHIKARI NKJ, HARTOG CS, TSAGANOS T, SCHLATTMANN P, ANGUS DC, REINHART K, INTERNATIONAL FORUM OF ACUTE CARE TRIALISTS: Assessment of global incidence and mortality of hospital-treated sepsis. current estimates and limitations. Am J Respir Crit Care Med 193: 259-272, 2016.

FREDRIKSSON K, HAMMARQVIST F, STRIGÅRD K, HULTENBY K, LJUNGQVIST O, WERNERMAN J, ROOYACKERS O: Derangements in mitochondrial metabolism in intercostal and leg muscle of critically ill patients with sepsis-induced multiple organ failure. Am J Physiol Endocrinol Metab 291: E1044-E1050, 2006.

FREISE H, BRÜCKNER UB, SPIEGEL HU: Animal models of sepsis. J Invest Surg 14: 195-212, 2001.

FREZZA C, CIPOLAT S, SCORRANO L: Organelle isolation: Functional mitochondria from mouse liver, muscle and cultured fibroblasts. Nat Protoc 2: 287-295, 2007.

FUJIWARA R, YODA E, TUKEY RH: Species differences in drug glucuronidation: Humanized UDP-glucuronosyltransferase 1 mice and their application for predicting drug glucuronidation and druginduced toxicity in humans. Drug Metab Pharmacokinet 33: 9-16, 2018.

GATTINONI L, BRAZZI L, PELOSI P, LATINI R, TOGNONI G, PESENTI A, FUMAGALLI R: A trial of goaloriented hemodynamic therapy in critically ill patients. N Engl J Med 333: 1025-1032, 1995.

GIRALDO E, GARCIA JJ, HINCHADO MD, ORTEGA E: Exercise intensity-dependent changes in the inflammatory response in sedentary women: role of neuroendocrine parameters in the neutrophil phagocytic process and the pro-/anti-inflammatory cytokine balance. Neuroimmunomodulation 16: 237-244, 2009.

GNAIGER E: Mitochondrial Pathways and Respiratory Control: An Introduction to OXPHOS Analysis. In: Mitochondrial Physiology Network 19.12. OROBOROS INSTRUMENTS Corp, Innsbruck, Austria, 2014.

GNAIGER E: Capacity of oxidative phosphorylation in human skeletal muscle: new perspectives of mitochondrial physiology. Int J Biochem Cell 41: 1837-1845, 2009.

GOMEZ H, INCE C, DE BACKER D, PICKKERS P, PAYEN D, HOTCHKISS J, KELLUM JA: A unified theory of sepsis-induced acute kidney injury: inflammation, microcirculatory dysfunction, bioenergetics, and the tubular cell adaptation to injury. Shock 41: 3-11, 2014.

HAYES MA, TIMMINS AC, YAU EH, PALAZZO M, WATSON D, HINDS CJ: Oxygen transport patterns in patients with sepsis syndrome or septic shock: influence of treatment and relationship to outcome. Crit Care Med 25: 926-936, 1997.

HEUSCH G, SCHULZ R, RAHIMTOOLA SH: Myocardial hibernation: a delicate balance. Am J Physiol Heart Circ Physiol 288: H984-H999, 2005.

HEYNDRICKX GR, MILLARD RW, MCRITCHIE RJ, MAROKO PR, VATNER SF: Regional myocardial functional and electrophysiological alterations after brief coronary artery occlusion in conscious dogs. J Clin Invest 56: 978-985, 1975.

HOTCHKISS RS, SONG SK, NEIL JJ, CHEN RD, MANCHESTER JK, KARL IE, LOWRY OH, ACKERMAN JJ: Sepsis does not impair tricarboxylic acid cycle in the heart. Am J Physiol 260: C50-C57, 1991.

HURST GD, JIGGINS FM: Problems with mitochondrial DNA as a marker in population, phylogeographic and phylogenetic studies: the effects of inherited symbionts. Proc Biol Sci 272: 1525-1534, 2005. 
INATA Y, KIKUCHI S, SAMRAJ RS, HAKE PW, O'CONNOR M, LEDFORD JR, O'CONNOR J, LAHNI P, WOLFE V, PIRAINO G, ZINGARELLI B: Autophagy and mitochondrial biogenesis impairment contribute to age-dependent liver injury in experimental sepsis: dysregulation of AMP-activated protein kinase pathway. FASEB J 32: 728-741, 2018.

JARDIN F, FOURME T, PAGE B, LOUBIÈRES Y, VIEILLARD-BARON A, BEAUCHET A, BOURDARIAS JP: Persistent preload defect in severe sepsis despite fluid loading: a longitudinal echocardiographic study in patients with septic shock. Chest 116: 1354-1359, 1999.

JEGER V, DJAFARZADEH S, JAKOB SM, TAKALA J: Mitochondrial function in sepsis. Eur J Clin Invest 43: 532-542, 2013.

KARARLI TT: Comparison of the gastrointestinal anatomy, physiology, and biochemistry of humans and commonly used laboratory animals. Biopharm Drug Dispos 16: 351-380, 1995.

KOZLOV A V, LANCASTER JR, MESZAROS AT, WEIDINGER A: Mitochondria-meditated pathways of organ failure upon inflammation. Redox Biol 13: 170-181, 2017.

KRAMER PA, CHACKO BK, RAVI S, JOHNSON MS, MITCHELL T, DARLEY-USMAR VM: Bioenergetics and the oxidative burst: protocols for the isolation and evaluation of human leukocytes and platelets. J Vis Exp $\mathbf{8 5}$ : $51301,2014$.

KREYMANN G, GROSSER S, BUGGISCH P, GOTTSCHALL C, MATTHAEI S, GRETEN H: Oxygen consumption and resting metabolic rate in sepsis, sepsis syndrome, and septic shock. Crit Care Med 21: 1012-1019, 1993.

KUZNETSOV A V, VEKSLER V, GELLERICH FN, SAKS V, MARGREITER R, KUNZ WS: Analysis of mitochondrial function in situ in permeabilized muscle fibers, tissues and cells. Nat Protoc 3: 965-976, 2008.

LANCEL S, HASSOUN SM, FAVORY R, DECOSTER B, MOTTERLINI R, NEVIERE R: Carbon monoxide rescues mice from lethal sepsis by supporting mitochondrial energetic metabolism and activating mitochondrial biogenesis. J Pharmacol Exp Ther 329: 641-648, 2009.

LANDESBERG G, GILON D, MEROZ Y, GEORGIEVA M, LEVIN PD, GOODMAN S, AVIDAN A, BEERI R, WEISSMAN C, JAFFE AS, SPRUNG CL: Diastolic dysfunction and mortality in severe sepsis and septic shock. Eur Heart J 33: 895-903, 2012.

LANGLEY RJ, TSALIK EL, VAN VELKINBURGH JC, GLICKMAN SW, RICE BJ, WANG C, CHEN B, CARIN L, SUAREZ A, MOHNEY RP, FREEMAN DH, WANG M, YOU J, WULFF J, THOMPSON JW, MOSELEY MA, REISINGER S, EDMONDS BT, GRINNELL B, NELSON DR, DINWIDDIE DL, MILLER NA, SAUNDERS CJ, SODEN SS, ROGERS AJ, GAZOURIAN L, FREDENBURGH LE, MASSARO AF, BARON RM, CHOI AM, COREY GR, GINSBURG GS, CAIRNS CB, OTERO RM, FOWLER VG JR, RIVERS EP, WOODS CW, KINGSMORE SF: An integrated clinico-metabolomic model improves prediction of death in sepsis. Sci Transl Med 5: 195ra95, 2013.

LEMIEUX H, BLIER PU, GNAIGER E: Remodeling pathway control of mitochondrial respiratory capacity by temperature in mouse heart: electron flow through the Q-junction in permeabilized fibers. Sci Rep 7: 2840, 2017.

LEVY MM, FINK MP, MARSHALL JC, ABRAHAM E, ANGUS D, COOK D, COHEN J, OPAL SM, VINCENT JL, RAMSAY G: 2001 SCCM/ESICM/ACCP/ATS/SIS International Sepsis Definitions Conference. Crit Care Med 31: 1250-1256, 2003.

LEWIS AJ, SEYMOUR CW, ROSENGART MR: Current murine models of sepsis. Surg Infect (Larchmt) 17: 385-393, 2016.

LIU X, REN H, PENG D: Sepsis biomarkers: an omics perspective. Front Med 8: 58-67, 2014.

LOFTUS TJ, KANNAN KB, CARTER CS, PLAZAS JM, MIRA JC, BRAKENRIDGE SC, LEEUWENBURGH C, EFRON PA, MOHR AM: Persistent injury-associated anemia and aging: Novel insights. $J$ Trauma Acute Care Surg 84: 490-496, 2018.

LUND N, DE ASLA RJ, CLADIS F, PAPADAKOS PJ, THORBORG PA: Dopexamine hydrochloride in septic shock: effects on oxygen delivery and oxygenation of gut, liver, and muscle. J Trauma 38: 767-775, 1995. 
MACDONALD MJ, LONGACRE MJ, STOKER SW, KENDRICK M, THONPHO A, BROWN LJ, HASAN NM, JITRAPAKDEE S, FUKAO T, HANSON MS, FERNANDEZ LA, ODORICO J: Differences between human and rodent pancreatic islets: low pyruvate carboxylase, ATP citrate lyase, and pyruvate carboxylation and high glucose-stimulated acetoacetate in human pancreatic islets. J Biol Chem 286: 18383-18396, 2011.

MAEDA Y, CHIDA J: Control of cell differentiation by mitochondria, typically evidenced in dictyostelium development. Biomolecules 3: 943-966, 2013.

MARIANO F, CANTALUPPI V, STELLA M, ROMANAZZI GM, ASSENZIO B, CAIRO M, BIANCONE L, TRIOLO G, RANIERI VM, CAMUSSI G: Circulating plasma factors induce tubular and glomerular alterations in septic burns patients. Crit Care 12: R42, 2008.

MARIK PE, TAEB AM: SIRS, qSOFA and new sepsis definition. J Thorac Dis 9: 943-945, 2017.

MARSHALL JC, DEITCH E, MOLDAWER LL, OPAL S, REDL H, VAN DER POLL T: Preclinical models of shock and sepsis: what can they tell us? Shock 24: 1-6, 2005.

MARTIN L, DERWALL M, THIEMERMANN C, SCHÜRHOLZ T: Heart in sepsis: Molecular mechanisms, diagnosis and therapy of septic cardiomyopathy. Anaesthesist 66: 479-490, 2017.

MATEJOVIC M, RADERMACHER P, ASFAR P: Sepsis, kidney, and tissue oxygenation: new methods, new insights, new perspectives? Shock 36: 99-100, 2011.

MATEJOVIC M, TUMA Z, MORAVEC J, VALESOVA L, SYKORA R, CHVOJKA J, BENES J, MARES J: Renal proteomic responses to severe sepsis and surgical trauma: dynamic analysis of porcine tissue biopsies. Shock 46: 453-464, 2016.

MATHEW R, PAL BHADRA M, BHADRA U: Insulin/insulin-like growth factor-1 signaling (IIS) based regulation of lifespan across species. Biogerontology 18: 35-53, 2017.

MATKOVICH SJ, AL KHIAMI B, EFIMOV IR, EVANS S, VADER J, JAIN A, BROWNSTEIN BH, HOTCHKISS RS, MANN DL: Widespread down-regulation of cardiac mitochondrial and sarcomeric genes in patients with sepsis. Crit Care Med 45: 407-414, 2017.

MELTON T, NELSON K: Forensic mitochondrial DNA analysis: two years of commercial casework experience in the United States. Croat Med J 42: 298-303, 2001.

MESTAS J, HUGHES CC: Of mice and not men: differences between mouse and human immunology. J Immunol 172: 2731-2738, 2004.

MILANI-NEJAD N, JANSSEN PML: Small and large animal models in cardiac contraction research: Advantages and disadvantages. Pharmacol Ther 141: 235-249, 2014.

MIYAJI T, HU X, YUEN PST, MURAMATSU Y, IYER S, HEWITT SM, STAR RA: Ethyl pyruvate decreases sepsis-induced acute renal failure and multiple organ damage in aged mice. Kidney Int 64: 1620-1631, 2003.

MÓDIS K, BOS EM, CALZIA E, VAN GOOR H, COLETTA C, PAPAPETROPOULOS A, HELLMICH MR, RADERMACHER P, BOUILLAUD F, SZABO C: Regulation of mitochondrial bioenergetic function by hydrogen sulfide. Part II. Pathophysiological and therapeutic aspects. Br J Pharmacol 171: 2123-2146, 2014.

MOOTHA VK, BUNKENBORG J, OLSEN J V, HJERRILD M, WISNIEWSKI JR, STAHL E, BOLOURI MS, RAY HN, SIHAG S, KAMAL M, PATTERSON N, LANDER ES, MANN M: Integrated analysis of protein composition, tissue diversity, and gene regulation in mouse mitochondria. Cell 115: 629-640, 2003.

OZKOK E, YORULMAZ H, ATES G, AKSU A, BALKIS N, ŞAHIN Ö, TAMER S: Amelioration of energy metabolism by melatonin in skeletal muscle of rats with LPS induced endotoxemia. Physiol Res 65: 833-842, 2016.

MRÁČEK T, DRAHOTA Z, HOUŠTĚK J: The function and the role of the mitochondrial glycerol-3-phosphate dehydrogenase in mammalian tissues. Biochim Biophys Acta 1827: 401-410, 2013.

PAGLIARINI DJ, CALVO SE, CHANG B, SHETH SA, VAFAI SB, ONG SE, WALFORD GA, SUGIANA C, BONEH A, CHEN WK, HILL DE, VIDAL M, EVANS JG, THORBURN DR, CARR SA, MOOTHA VK: A mitochondrial protein compendium elucidates complex i disease biology. Cell 134: 112-123, 2008.

PARKER MM, SHELHAMER JH, BACHARACH SL, GREEN M V, NATANSON C, FREDERICK TM, DAMSKE BA, PARRILLO JE: Profound but reversible myocardial depression in patients with septic shock. Ann Intern Med 100: 483-490, 1984. 
PATIL NK, PARAJULI N, MACMILLAN-CROW LA, MAYEUX PR: Inactivation of renal mitochondrial respiratory complexes and manganese superoxide dismutase during sepsis: mitochondria-targeted antioxidant mitigates injury. Am J Physiol Renal Physiol 306: F734-F743, 2014.

PECINOVÁ A, DRAHOTA Z, NU゚SKOVÁ H, PECINA P, HOUŠTĚK J: Evaluation of basic mitochondrial functions using rat tissue homogenates. Mitochondrion 11: 722-728, 2011.

PERRY CGR, KANE DA, LANZA IR, NEUFER PD: Methods for assessing mitochondrial function in diabetes. Diabetes 62: 1041-1053, 2013.

PESTA D, GNAIGER E: High-resolution respirometry: OXPHOS protocols for human cells and permeabilized fibers from small biopsies of human muscle. Methods Mol Biol 810: 25-58, 2012.

PIERRAKOS C, VINCENT JL: Sepsis biomarkers: a review. Crit Care 14: R15, 2010.

PINTO BB, DYSON A, UMBRELLO M, CARRÉ JE, RITTER C, CLATWORTHY I, DUCHEN MR, SINGER M: improved survival in a long-term rat model of sepsis is associated with reduced mitochondrial calcium uptake despite increased energetic demand. Crit Care Med 45: e840-e848, 2017.

PIPER HM, SEZER O, SCHLEYER M, SCHWARTZ P, HÜTTER JF, SPIECKERMANN PG: Development of ischemia-induced damage in defined mitochondrial subpopulations. J Mol Cell Cardiol 17: 885-896, 1985.

PITTS LR, SIMPSON SQ: From mice to men: systematic reviews of animal data could make sepsis trials safer and more productive. Crit Care Med 38: 2420-2422, 2010.

POLI-DE-FIGUEIREDO LF, GARRIDO AG, NAKAGAWA N, SANNOMIYA P: Experimental models of sepsis and their clinical relevance. Shock 30: 53-59, 2008.

PORTA F, TAKALA J, WEIKERT C, BRACHT H, KOLAROVA A, LAUTERBURG BH, BOROTTO E, JAKOB SM: Effects of prolonged endotoxemia on liver, skeletal muscle and kidney mitochondrial function. Crit Care 10: R118, 2006.

PUSKARICH MA, KLINE JA, WATTS JA, SHIREY K, HOSLER J, JONES AE: Early alterations in platelet mitochondrial function are associated with survival and organ failure in patients with septic shock. $J$ Crit Care 31: 63-67, 2016.

RAHIMTOOLA SH: The hibernating myocardium in ischaemia and congestive heart failure. Eur Heart $J$ 14: 22-26, 1993.

RAMOS-FILHO D, CHICAYBAM G, DE-SOUZA-FERREIRA E, GUERRA MARTINEZ C, KURTENBACH E, CASIMIRO-LOPES G, GALINA A: High intensity interval training (HIIT) induces specific changes in respiration and electron leakage in the mitochondria of different rat skeletal muscles. PLoS One 10: e0131766, 2015.

RAUCHOVÁ H, VOKURKOVÁ M, DRAHOTA Z: Inhibition of mitochondrial glycerol-3-phosphate dehydrogenase by $\alpha$-tocopheryl succinate. Int J Biochem Cell Biol 53: 409-413, 2014.

REDL H, BAHRAMI S: Large animal models: baboons for trauma, shock, and sepsis studies. Shock 24: 88-93, 2005.

REINHART K, BAUER M, RIEDEMANN NC, HARTOG CS: New approaches to sepsis: molecular diagnostics and biomarkers. Clin Microbiol Rev 25: 609-634, 2012.

RITTIRSCH D, HOESEL LM, WARD PA: The disconnect between animal models of sepsis and human sepsis. J Leukoc Biol 81: 137-143, 2007.

SEOK J, WARREN HS, CUENCA AG, MINDRINOS MN, BAKER HV, XU W, RICHARDS DR, MCDONALDSMITH GP, GAO H, HENNESSY L, FINNERTY CC, LÓPEZ CM, HONARI S, MOORE EE, MINEI JP, CUSCHIERI J, BANKEY PE, JOHNSON JL, SPERRY J, NATHENS AB, BILLIAR TR, WEST MA, JESCHKE MG, KLEIN MB, GAMELLI RL, GIBRAN NS, BROWNSTEIN BH, MILLER-GRAZIANO C, CALVANO SE, MASON PH, COBB JP, RAHME LG, LOWRY SF, MAIER RV, MOLDAWER LL, HERNDON DN, DAVIS RW, XIAO W, TOMPKINS RG; INFLAMMATION AND HOST RESPONSE TO INJURY LSCRP: Genomic responses in mouse models poorly mimic human inflammatory diseases. Proc Natl Acad Sci U S A 110: 3507-3512, 2013.

SEVILLA BERRIOS RA, O'HORO JC, VELAGAPUDI V, PULIDO JN: Correlation of left ventricular systolic dysfunction determined by low ejection fraction and 30-day mortality in patients with severe sepsis and septic shock: a systematic review and meta-analysis. J Crit Care 29: 495-499, 2014. 
SCHÖPF B, SCHÄFER G, WEBER A, TALASZ H, EDER IE, KLOCKER H, GNAIGER E: Oxidative phosphorylation and mitochondrial function differ between human prostate tissue and cultured cells. FEBS J 283: 2181-2196, 2016.

SCHUBERT KA, BOEREMA AS, VAANHOLT LM, DE BOER SF, STRIJKSTRA AM, DAAN S: Daily torpor in mice: high foraging costs trigger energy-saving hypothermia. Biol Lett 6: 132-135, 2010.

SHARMA SK, NAIDU G: The role of danger-associated molecular patterns (DAMPs) in trauma and infections. J Thorac Dis 8: 1406-1409.

SIEMPOS II, LAM HC, DING Y, CHOI ME, CHOI AMK, RYTER SW: Cecal ligation and puncture-induced sepsis as a model to study autophagy in mice. J Vis Exp 84: 51066, 2014.

SINGER M: Mitochondrial function in sepsis: acute phase versus multiple organ failure. Crit Care Med 35 (9 Suppl): S441-S448, 2007.

SINGER M: The role of mitochondrial dysfunction in sepsis-induced multi-organ failure. Virulence 5: 66-72, 2014.

SINGER M: Critical illness and flat batteries. Crit Care 21: 309, 2017.

SINGER M, DEUTSCHMAN CS, SEYMOUR CW, SHANKAR-HARI M, ANNANE D, BAUER M, BELLOMO R, BERNARD GR, CHICHE JD, COOPERSMITH CM, HOTCHKISS RS, LEVY MM, MARSHALL JC, MARTIN GS, OPAL SM, RUBENFELD GD, VAN DER POLL T, VINCENT JL, ANGUS DC: The Third International Consensus Definitions for Sepsis and Septic Shock (Sepsis-3). JAMA 315: 801-810, 2016.

SJÖVALL F, MOROTA S, HANSSON MJ, FRIBERG H, GNAIGER E, ELMÉR E: Temporal increase of platelet mitochondrial respiration is negatively associated with clinical outcome in patients with sepsis. Crit Care 14: $\mathrm{R} 214,2010$.

STANDAGE SW, BENNION BG, KNOWLES TO, LEDEE DR, PORTMAN MA, MCGUIRE JK, LILES WC, OLSON AK: PPAR $\alpha$ augments heart function and cardiac fatty acid oxidation in early experimental polymicrobial sepsis. Am J Physiol Heart Circ Physiol 312: H239-H249, 2017.

STONEKING M, SOODYALL H: Human evolution and the mitochondrial genome. Curr Opin Genet Dev 6: 731-736, 1996.

STORTZ JA, RAYMOND SL, MIRA JC, MOLDAWER LL, MOHR AM, EFRON PA: Murine models of sepsis and trauma: can we bridge the gap? ILAR J 58: 90-105, 2017.

TANTAMA M, MARTÍNEZ-FRANÇOIS JR, MONGEON R, YELLEN G: Imaging energy status in live cells with a fluorescent biosensor of the intracellular ATP-to-ADP ratio. Nat Commun 4: 2550, 2013.

UMBARAWAN Y, SYAMSUNARNO MRAA, OBINATA H, YAMAGUCHI A, SUNAGA H, MATSUI H, HISHIKI T, MATSUURA T, KOITABASHI N, OBOKATA M, HANAOKA H, HAQUE A, KUNIMOTO F, TSUSHIMA Y, SUEMATSU M, KURABAYASHI M, ISO T: Robust suppression of cardiac energy catabolism with marked accumulation of energy substrates during lipopolysaccharide-induced cardiac dysfunction in mice. Metabolism 77: 47-57, 2017.

VAN DER POLL T: Preclinical sepsis models. Surg Infect (Larchmt) 13: 287-292, 2012.

VANASCO V, SAEZ T, MAGNANI ND, PEREYRA L, MARCHINI T, CORACH A, VACCARO MI, CORACH D, EVELSON P, ALVAREZ S: Cardiac mitochondrial biogenesis in endotoxemia is not accompanied by mitochondrial function recovery. Free Radic Biol Med 77: 1-9, 2014.

VELAYUTHAM M, HEMANN CF, CARDOUNEL AJ, ZWEIER JL: Sulfite oxidase activity of cytochrome c: role of hydrogen peroxide. Biochem Biophys Rep 5: 96-104, 2016.

VILLAR J, MACA-MEYER N, PÉREZ-MÉNDEZ L, FLORES C: Bench-to-bedside review: understanding genetic predisposition to sepsis. Crit Care 8: 180-189, 2004.

WALTZ P, CARCHMAN E, GOMEZ H, ZUCKERBRAUN B: Sepsis results in an altered renal metabolic and osmolyte profile. J Surg Res 202: 8-12, 2016.

WÜST RC, HELMES M, STIENEN GJ: Rapid changes in NADH and flavin autofluorescence in rat cardiac trabeculae reveal large mitochondrial complex II reserve capacity. J Physiol 593: 1829-1840, 2015.

ZANOTTI-CAVAZZONI SL, GOLDFARB RD: Animal models of sepsis. Crit Care Clin 25: 703-719, 2009. 